
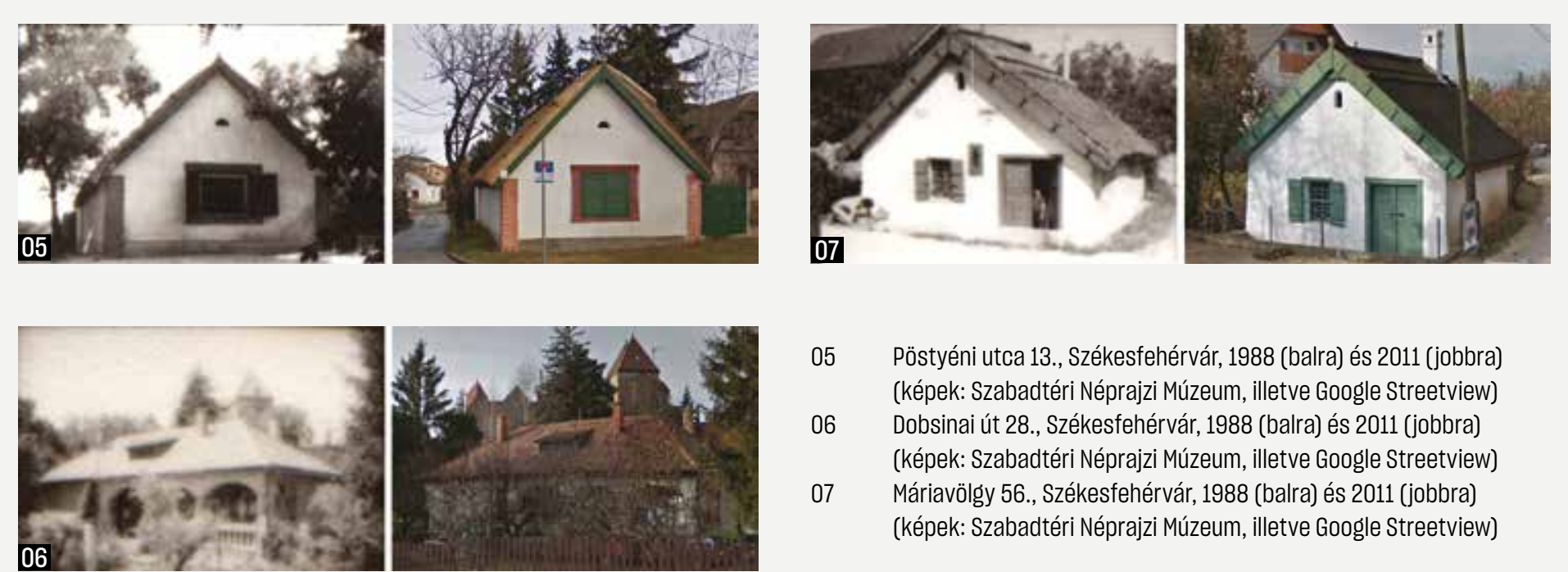

05 Pöstyéni utca 13., Székesfehérvár, 1988 (balra) és 2011 (jobbra) (képek: Szabadtéri Néprajizi Múzeum, illetve Google Streetview) Dobsinai út 28., Székesfehérvár 1988 (balra) és 2011 (jobbra) (képek: Szabadtéri Népraji Múzzeum, illetve Gooóle Streetview) MáriavöIgy $56 .$, Székestenérérár, 1988 (balra) és 2011 (jobbra) (képkek Szabadtéri Néprajiz Múzeum, illetve Goosle Stroetview)

mennyire megalapozottak ezek a várakozások, illetve mi a kulcsa a tartós földfalaknak. Szükséges-e valán kibújhatnak a vályogházak ebből a népviseletbőll? Ez doktori kutatásom központi kérdése, végső soron ezeket az empirikus tapasztalatokat, kikísérletezett szerkezeti kialakításokat szeretném tudományos módszerekkel ellenőrizni, és alátámasztani vagy megcáfoln

_-Egy ilyen kérdés megválaszolásához több úton kell vizsgálódni párhuzamosan. Mindegyik útnak megvannak az előnyei és hátrányai. Az egyes tényezők hatását külön-külön vizsgálni a legjobban laboratóriumi körülmények között lehet. Az egyes anyagösszetételek, építési technikák, illetve felületkezelések hatását kültéren megépitett próbafalako is szokták vizsgálni. A tényleges has nálat soran nyujitott teljesítményrôl szolgál információval a meglévo epületek vizsgálata. Jelen cikkben ez utóbbiba szeretnék betekintést adni az olvasónak.

\section{MEGLÉVŐ VÁLYOGHÁZAK}

VIZSGÁLATA

— A meglévő épületek vizsgálata töb vonatkozásban tud információval szolgálni kutatâsi kérdésem megvấlaszolásában. Alényegi vonatkozás a hagyományosan védelmet adó szerkezeti elemeknek (nagy ereszkinyúlás, fagyálló lábazat, meszelés) a fal állagvédelmében betöltött szerepének meghatározása. Ideális esetbe megallapithato az egyes szerkeze elemek állagromlást fékezỏ teljesimênye kúlonn-külon is, de az egyes elemek között legalább egy sorrendiséget fel lehet állítani.
— A meglévő házak reprezentaa fentiekhez. A vizsgálat központi kédése, hogy az egyes épületek állagromlásának üteme mutat-e, illetve milyen mértékú összefüggést mutat az egyes, védelmet adó szerkezet elemek jelenlétével. Az állagromlás ütemének megállapításához vagy
hosszan elnyúló megfigyelésre vagy tulajdonosi/lakói nyilatkozatokra kell támaszkodni. Az elóbbi egy doktori kutatás időkkeretén bőven túlmutat, az utóbbi megbízhatósága pedig megkérdőjelezhetón.

_ Megoldást jelenthet, ha a mintát úgy tudjuk megválasztani, hogy a benne szerepló épületekről korábban már készült állapotfelmérés. Egy ilyen korábbi állapotfelmérés a tulajdonosoknak szóló kérdőívvel, illetve mostani felméréssel kiegészítve má használható információval tud szolgálni az allagromlás ütemének megállapítására, különösen, ha az erede felmérés fotódokumentációt is

\section{tartalmaz}

_ Jelenleg ennek a mintának az összeállitásán dolgozom, ehhez keresem a megfeleló épületeket. A Magyarországon található vályog házak számáról a 200I-es és zoII-es népszamláăâsi adatok adnak informáciot. [2; 4] Ezek alapjan 20II-be közel 700 ezer lakott vályogház volt hazánkban. A fenti szempontok seg tettek leszukiteni, hogy ebből a sok szåzezer hazboól melyeket êrdemes bevenni a vizsgálatba, mégpedig azokat, melyekről

2. van róluk korábbi fénykép és

3. ezek újbóli elkészítésére is van lehetóség.

_ Az elsỏ két pont a szűk keresztmetszet, de szerencsére hazánkban hosszú múltra tekintenek vissza a felmérỏtáborok, népi építészeti gyứ Múzeum (Skanzen) több ilyen gyüjteményt is tárol, többek között a dr. Szabó László által 25 éven keresztuil vezetett Népi Tudományos Diákkör (NTDK) felmérési rajzait, dia-, illetve fotóanyagát. Ez volt az első gyúitemény, amelyet a fenti célokra megpro báltam felhasználni. A cikk hátralévó részében ennek első eredményeit mutatom be.

\section{AZ NTDK NYOMÁBAN}

- AZNTDK minden évben más helyszinen táborozott, és a résztvevók számátol függoen több vagy kevesebb épületet mert fel. (2. kép) A felmért epületek nagy része lakó- és/ vagy csatlakozo gazdasági épület. [6] Ez onmagaban nem jelent garanciá arra, hogy ezek falai földbỏl készültek, de valoszinusithetó, így a kezdeti fázisban az egyszerüség kedvéért ezt feltételeztem. Az utánkövetésre érdeam ki, hogy a kutatás szempontjából hány releváns épületet dolgoztak fel a felméréskor. Az öt legtermékenyebb helyszint a 3. kép mutatja, a felmért epületek szamával együtt. Az 1992-es Szanticskán es Goncon megrendezett relmerotábor is szoba jonne, azonban a két telepules távolsaga miatt ezt két külön helyszínként kezeltem. - Az utánkövetéshez a felmért épületeket fel is kell keresni, azonban egyik esetben sincs garancia, hogy az adott epület ma is állna. Ez a fenti hármas követelmény utolsó elvárása. Annak elózetes megitélésére, hogy hol és hány épület maradt állva, a Goog Streetview szolgáltatását lehet igénybe venni. Ez a szolgáltatás nem minden érintett településen elérhetô

Tás és falazat szerint, Településtípusonkénti adatok, Területi adatok - Fejér Megyye, Népszámlálás 2001, hozzátérhetö: - http: ://nepszamlalas2001.hu/hun/ (20)

11 lakott lakások szobaszám, épitési év, használati jogccím, lakás-alapterület, felszereltsége, fưtési mód és falazat szerint, 2011 Székesfehérvár mij, Településtípusonkénti adatok, Területi adatok - Fejér Megye, Népszámlálás 2011, hozzáférhetô: : htttp://Iwww.ksh.hu/nepszamlalas (2020-10-26.

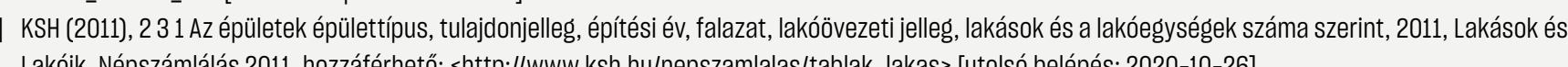

[5] Morel, J C - Bui, Q B - Venkatarama Reddy, B R - Ghayad, W: „Durability of rammed earth walls exposed for 20 years to natural weathering", Building and Environment, Issue 44 (2009) pp 912-919, DoI: <10.1016/j.buildenv.2008.07.001

[6] Szabó, László: Népi épitészeti gyökerek felmérése, kutatása diákjaimmal 1976-2001, Épitésügyi Tájékoztatási Központ, Budapest 2003, ISBN 963-513-173-9.

[7] Van Damme, Henri - Houben, Hugoo: ,Earth concrete - Stabilization revisited", Cement and Concrete Research, Issue 114 (2018) pp 90-102, DoI: 40.1016/j.cemconres.2017.02.035 teljeskörủen, a kisebb települések
esetében általában csak a fóutcáról van ilyen adat.

_ Az öt legtöbb felmért épülettel rendelkező helyszín közzï Krasznokvajda és környéke, illetve Tiszadob is olyan, ahol a kérdéses épületek közül csupán I-2 található meg a Google utcakép-szolgáltatá sában. A maradék három helyszín összes épületét végignézve négy kategóriába lehet sorolni őket: fennmaradt, bizonytalan, megszünt vagy ismeretlen.

_ 'Fennmaradtnak' tekintettem az olyan épületeket, amelyeknél a legfrissebb utcaképen egvértelmủen a felmérés célpontjai közé tartozó népi épületet látunk. Sok esetben már ez is csak I-2, esetenként 8 évvel ezelőtti információt jelent. 'Bizonytalan' az, ahol a Google szolgáltatásban szerepló utca vagy házszám nem egyezik a dokumentáciôban megjelölttel, vagy látszòdik egy ház, de a felmérési rajzok hiannyảban nem megállapitható hogy ugyanarrol az epületrő́l van-e szó. 'Megszuntnek' tekinthetó az az épület, ahol az adott házszám alat üres telek vagy egyértelmủen nem népi épület látható. 'Ismeretlennek' neveztem azt a kategoriát, amelyröl a Google szolgáltatásban nincs információ. Az ezek alapján összegzett adatokat a 4. kép mutatja. _A 4. kepen szereplo három település népességszám alapján három különbözo kategoriát képvisel, Sümeg hatezer, Nagykörös huszonharomezer, mig Szekesfehervár kilencvenhatezer fós város. Jól láthato, hogy a 8o-as években felmért épületekhez képest arányában több, illetve ehhez képest Sümege a legkevesebb. Tehát az elmúlt 32 év alatt a székesfehérvári felmért épületek $58 \%$-át a fenti adatok alapján már elbontották, s további $16 \%$ státusza bizonytalan. A KSH adatai alapján azonban ez a pusztutás nem egyenletes ütemben zajlot le. A népszámlálások adatai alapján Székesfehérváron 200r-ben összesen 478 lakott vályogfalú lakás volt, [2] ami 20I-re I48-ra csökkent, [3] ez a $69 \%$-os fogyás megfelel az elóbbi értéknek, de 32 év helyett to év leforgása alatt történt. A másik két városra vonatkozóan sajnos ilyen adat nem elérhetőo, így az ottani pusztulás mértékét nem tudjuk a statisz kai adatokkal összehasonlítani. — A fenti módon meghatározot épületek körét tovább szúkíti a második feltétel: a fotódokumentáció. Az NTDK 25 éves évfordulójára kiado könyv [6] tanúsága szerint elkészül fotódokumentációnak sajnos több epulet esetében is nyoma veszett. A cikk írasakor igy egykori és mai fényképeket mindösszesen három székesfehérvári épületre vonatkozoan lehetseges egymas mellé tenn (5., 6. és 7. kepek) A többi településhez tartozó fotódokumentációhoz eddig mèg egyáltalàn nem sikerült hozzajutnom. Feltételezhetően ezekrôl nemcsak egy példány van, hanem az eredeti fotók, diafilmek megt lálhatók más helyen is (a települések onkormanyzatan vagy dr. Szabó László személyes gyüjteményében).

ÖSSZEGZÉS

— Az eddigiekból megállapítható, hogy igencsak munkaigényes felada a cikk elsỏ felében meghatarozott harmas kovetelmenynek eleget tevo épületek beazonosítása. Az NTDKanyag esetében a módszer kevésbé

volt eredményes - az 5-7. képeken látható fényképpárokból nem sok állagbeli változás figyelhetó meg alyan épületekekról található fényké p. amelyeket azóta is karbantartottak, illetve felújítottak, egyelőre csupán a véletlennek tulajdonítható. _ A módszer maga célravezetônek tủnik, így más, jobban feldolgozott. digitalizált gyuüjtemények felhaszná lása is indokolt. További lehetséges forrás a Skanzen egy másik gyứjteménye, a Magyar Népi Építészeti Gyújtemény, mely Vargha László és munkatársainak felmérési dokumentációit tartalmazza. A Skanzen honlapja szerint a gyủitemény majdnem I9 ezer fényképet és közel 4 ezer diapozitivot tartalmaz, a felme rési anyagban szerepló egyéb rajzos, irásos dokumentumok szâma 2597 darab. Az NTDK-anyaghoz képest ez a fényképes dokumentáció nagyságrendekkel nagyobb, s a közel I9 ezer fényképból 6600 már digitalizalva van, ani a további feldolgozás is megkönnyitheti.

— Az épületek különbözỏ időpillanatokban lévő állapotának összehasonlításara elengedhetetlen a korábbi felmérési adatok és fentyképek összehasonlitása a maiakkal. Ettől függetlenül az öregedési folyamatról nem tudunk teljes képet alkotni, amíg 


\section{ABSTRACTS}

MIZSEI, Anett: WELL WORKING MACHINERY TO CONTEMPORARY ART Citation: Metszet, Vol17, No 6 (2020) pp 8-15. DO1. 10.33268/Met 2020.67 AQUATICUM STRAND, DEBRECEN, HUNGARY / Architect PÉTER BORDÁs $\begin{array}{ll}\text { to create a sustainable building complex. } & \text { upwards to create water slides, fountains and } \\ \text { other architectural features. Bravely placed }\end{array}$

bridges accentuate the sculptural aspect of
this design. Planting also plays an importan role in this scheme with green roofs and vertical planted walls.

KATONA, Vilmos: KOOLHAAS AND THE KOREAN WONDER WEAPON Citation: Metszet, Vol 11, No 6 (2020), pp 16-21, DOI: 10.33268/Met.2020.6 2 MKOOLHAAS hat fuse commercial and cultural activities a parametric sase study. Is this project to be

Ilimits of what can be transferred from digital within psychological constraints possibly

\section{WARE-NAGY, Orsolya: BIG OFFICE, BIG TOWN, BIG PROJECT}

Citation: Metszet, Vol 17, No 6 (2020), pp 22-27, DOI: 10.33268/Met.2020.6.3

SILK ROAD INTERNATIONAL CONVENTION CENTRE, XI'AN, CHINA | Architect: MEINHARD von GERKAN, NIKOLAUS GOETZE and MAGDELENE WEII

The size of this building is hard to visually the refined use of structural and curtain wall accuracy of detailing steelwork and BIM elements. Detailed to seemingly float above working methods. Initially a period of 300 days was expected to reach structural completion,
this was achieved in 90 days. Prefabrication being the key to success.

\section{FUNK, Bogdán: TROPICAL TEACHING MACHINE}

Citation: Metszet, Vol 17, No 6 (2020), pp 28-33, DOI: 10.33268/Met.2020.6.

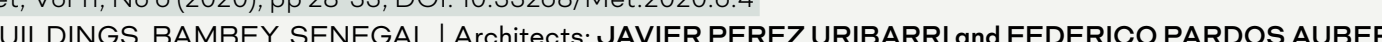

$\begin{array}{lll}\text { Inspired by the existing landscape and } & \text { reworking of LeCorbusier's Machine for Living. } & \text { treatment systems. The core of the building } \\ \text { trees the new university buildings have } & \text { Unlike machines this building employs its built } & \text { working like a tree trunk supporting the canopy } \\ \text { been designed to work in harmony with } & \text { form as a shading device, and temperature } & \text { like roof. } \\ \text { the environment creating a metaphorical } & \text { control, rainwater management and waste } & \end{array}$
the environment creating a metaphorical control, rainwater management and waste

WESSELEENYI-GARAY, Andor: STRUCTURE AS ORNAMENT Citation: Metszet, Vol 11, No 6 (2020), pp 34-39, DOI: 10.33268/Met.2020.6.5 Restoration Architects: MARGEL FERENCZ and GYÖRGY DÉTÁR

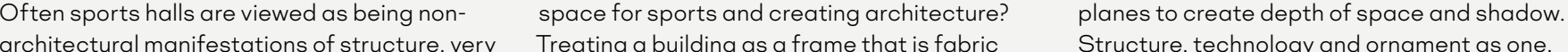
$\begin{array}{llll}\text { architectural manifestations of structure, very Treating a building as a frame that is fabric } & \text { Structure, technology and ornament as one. } \\ \text { little soul with little in terms of character. So } & \text { covered or, as in this case treating structural What is allowed? What are we used to? What }\end{array}$ $\begin{array}{ll}\text { little soul, with little in terms of character. So } & \begin{array}{l}\text { covered or, as in this case treating structural } \\ \text { coverings as a graphical tool: extruding }\end{array}\end{array}$

\section{CSANÁDY, Pál: EXTRA MUROS}

Citation: Metszet, Vol 11, No 6 (2020), pp 40-45, DOI: 10.33268/Met.2020.6.6

MARKET HALL, PÁPA, HUNGARY | Restoration Architects: CSABA NÉMETH and FERENC PENG

As with many larger towns in Hungary $\quad$ hall encloses covered permanent market pavilions. What sets this project aside

terminus. To replace this a competition was side, administration offices and public $\quad$ galvanized steel, pergola.

\section{NÉMETH, CSABA: KEF-ILK IN SZABOLCS UTCA}

Citation: Metszet, Vol 11, No 6 (2020), pp 46-49, DOI: 10.33268/Met.2020.6.7

former hospital buildings dating back to 1908 , character in a suitable manner for the

$\begin{array}{ll}\text { redevelopment as a modern office building } & \text { guncenfield development that has a good visual }\end{array}$

tion to the former hospital building that compliments the OMRRK buildings on the

PATAKY, RITA: Thoughts on developing the sloping roof and insulation

Citation: Metszet, Vol 11, No 6 (2020), pp 50-55, D DOl: 10.33268/Met.2020.6.8

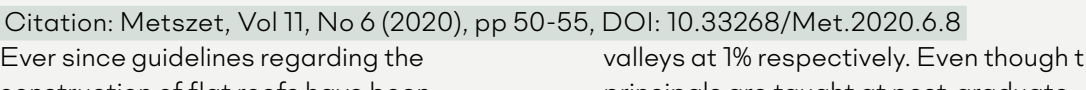

construction of flat roofs have been principals are taught at post-graduate

$\begin{array}{ll}\text { firloduced it is well known that roofs must } & \text { level, the task seems routine, however } \\ \text { experience shows that practice is often more }\end{array}$

ex. The article about Budapest One

BIRGHOFFER, PÉTER: RECONSTRUCTION OF THE HORSE-RIDING HALL ON BUDA CASTL

Citation: Metszet, Vol 11, No 6 (2020), pp 56-61, DOI: 10.33268/Met.2020.6.9

In professional aircles interest in this Horse- technology has been aroused. After all, it is roof, it is the idea of employing contemporary
DÉTÁRI, GYÖRGY - REISCH, RICHÁRD: RAINWATER DRAINAGE AT THE NEW ETHNOGRAPHIC MUSEUM Citation: Metszet, Vol 11, No 6 (2020), pp 62-67, DOI: 10.33268/Met.2020.6.10

the historic entrane to City Park The subject drains above and rouf garden. The number of reduced, and the design process completed reduced and the water had to be drained. The mind the edge conditions.

KOVACS, KAROLYLEHEL-REISCH, RICHARD.INSULATION CHALLENGES OF PARAMETRICALLY DESIGNED ROOF SURFACES Citation: Metszet, Vol 11, No 6 (2020), pp 68-73, DOI: 10.33268/Met.2020.6.11

Sou Fujimoto, the Japanese arohteot, requiring new engineering solutions. This concepts precisely defined and design stages, $\begin{array}{lll}\text { imagined the House of Hungarian Music at } \\ \begin{array}{l}\text { City Park. The building's roof geometry goes } \\ \text { against traditional design methods, which }\end{array} & \begin{array}{l}\text { article shows the structure via parametric, } \\ \text { computer assisted modelling, a double curved } \\ \text { shell's water proofing and insulatation. Technical }\end{array} & \begin{array}{l}\text { the development of the details. Summary of } \\ \text { reasons and suggestions regarding changes } \\ \text { made during the construction period. }\end{array}\end{array}$

FÉLIX, ZSOLT - KAPOVITS, GÉZA: LESSONS FROM AN OFFICE BUILDING

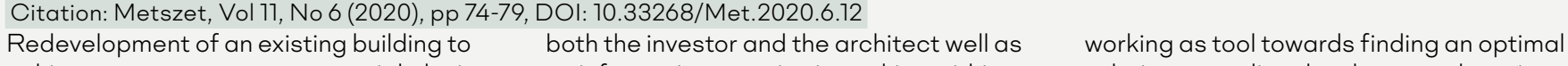
$\begin{array}{ll}\begin{array}{l}\text { achieve contemporary commercial, design } \\ \text { and environmental standards has served }\end{array} & \text { a informative exercise in working within } \\ \text { a given, built, framework. Architecture } & \text { solution regarding development, location } \\ \text { and continued facility management ideals. }\end{array}$

\section{HEINZ, DÁNIEL - KAPOVITS, GÉZA: SAINT MARGIT GYMNASIUM}

HEINZ, DANIEL-KAPOVITS, GEZA: SAINT MARGIT GYMNASIUM
Citation: Metszet, Vol 17, No 6 (2020), pp 80-85, DOI: 10.33268/Met.2020.6.13

water, a flat roof which is also a football pitch program and the number of people are limited, we show the structure regarding the thermal and all the issues which arrive from the new on the hillside and the architect's attitude and shell of the building, protection against ground technologies.

BECKER, GÁBOR: FROM ANCIENT TIMES TO THE PRESENT - BYTES FROM THE PAST AND PRESENT OF PREFABRICATION Citation: Metszet, Vol 11, No 6 (2020), pp 86-91, DOI: 10.33268/Met.2020.6.14

$\begin{array}{ll}\text { steel structures of the modern age. Nowas ancient Greek temples and medieval } & \text { from America to Japan prefabrication is }\end{array}$

HUNYADI, ZOLTÁN: ENFORCEMENT OF ACOUSTIC QUALITY STANDARDS FOR RESIDENTIAL BUILDINGS IN THE LIGHT OF CURRENT REQUIREMENTS

Citation: Metszet, Vol 11, No 6 (2020), pp 92-97, DOI: 10.33268/Met.2020.6.15

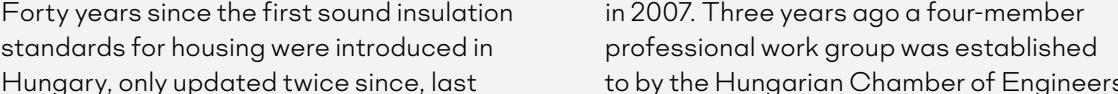

their findings have not been acted upon even to by the Hungarian Chamber of Engineers, noise events suggest it is time to re-review.

MESTERHÁZY, BEÁTA: THE MOST IMPORTANT EXPERIENCES GAINED DURING OPERATION OF THE BME BUILDING

Citation: Metszet, Vol 17, No 6 (2020), pp 98-103, DOI: 10.33268/Met.2020.6.16

Since the mid-1970s but has had a Building tests, results have been puble

Acoustics Laboratory working closely in 1995 and 2011 emphasis was placed on the

covers roofs and provides an overview of partnership with the department of building
structures. Aside from educational research
establishtion of specific walls structures to

TAKÁCS, LAJOS - SZIKRA, CSABA - ZSITVA, ATTILA: FIRE SPREAD PREVENTION FOR ELEVATIONS WITH NON-FIRE RATED GLAZING

Citation: Metszet, Vol 11, No 6 (2020), pp 104-109, DOI: 10.33268/Met.2020.6.17

fire resistant is possible, this path is rarely equipment - window sprinklers - without a fire

$\begin{aligned} & \text { chosen due to its cost. According to the } \\ & \text { current National Fire Protection Regulations, }\end{aligned}$
resistance limit value can only be designed
anstalled on the basis of a real-scale,

ffective fire test. Our article looks for an answer for glazed structures with built-in fire
extinguishers and curtain walls with limited

TAKÁCS, LAJOS - SZIKRA, CSABA: FLOW TESTING OF DOCKING GATES TO HALL BUILDINGS TAKING INTO ACCOUNT HEAT AND SMOKE EXTRACTION

Citation: Metszet, Vol 11, No 6 (2020), pp 110-115, DOI: 10.33268/Met.2020.6.18

This article examines the heat and smoke The geometry and materials used in the

buildings at docking gates. Airflow rates

construction of docks, how this can be
numerically simulated to assist in the

fire. The legal background and implications design process for movement of air during

ocking areas and their

MEDVEY, BOLDIZSÁR: FOLK SCIENCE STUDENT CIRCLE USABILITY OF RESEARCH SURVEYS Citation: Metszet, Vol 11, No 6 (2020), pp 116--119, DOI: 10.33268/Met.2020.6.19

Contemporary adobe architecture seems some pioneering examples do not require

building materials. Brave moves to exposen

adobe structures are made possible when

these pical additives. Seeing the success of

existing buildings to see how they function as

the fare without their ominous hats and boots. research of the Folk Science Student Circle.

a building material use type and how would 